\title{
COX-2 regulates Snail expression in gastric cancer via the Notch1 signaling pathway
}

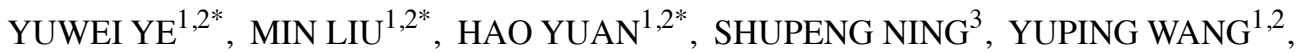 \\ ZHAOFENG CHEN ${ }^{1,2}$, RUI JI ${ }^{1}$, QINGHONG GUO ${ }^{1}$, QIANG $\mathrm{LI}^{1}$ and YONGNING ZHOU ${ }^{1,2}$ \\ ${ }^{1}$ Division of Gastroenterology and Hepatology, The First Hospital of Lanzhou University; \\ ${ }^{2}$ Key Laboratory for Gastrointestinal Diseases of Gansu Province, Lanzhou University; ${ }^{3}$ Department of Anesthesiology, \\ The Second Hospital of Lanzhou University, Lanzhou, Gansu 730000, P.R. China
}

Received November 1, 2016; Accepted May 19, 2017

DOI: $10.3892 / \mathrm{ijmm} .2017 .3011$

\begin{abstract}
The conversion of arachidonic acid into prostaglandins by cyclooxygenase (COX)-2 contributes to the biological properties of malignant tumours. During the initiation and development of various tumours, the Notch family plays a key role. However, the association between COX-2 and the Notch family in gastric cancer (GC) remains unclear. The present study aimed to clarify the mechanisms through which COX-2 participates in the pathogenesis of GC. Quantitative PCR and western blot analysis were used to detect the expression of Notch family members and COX-2 in human GC and paracancerous tissues, GES-1 cells and GC cell lines (AGS, SGC-7901, BGC-823, and MGC-803) treated with or without celecoxib, prostaglandin E2 and small interfering RNA (siRNA). A CCK-8 assay was performed to detect the proliferation of GC cells transfected with siRNA against COX-2 (si-COX-2). A high mRNA expression of Notch1 and a decreased expression of Notch-1 intracellular active domain (N1IC) in GC were found to be related to the depth of invasion and TNM staging. The mRNA levels of Notch2, Notch3, Jagged1 and N2IC were found to be high in GC. A High expression of COX-2 was associated with poorly differentiated and deeply invasive GC. COX-2 and Notch1 exhibited an inverse expression pattern in the GES-1 cells and different GC cell lines; the inhibition of COX-2 increased Notch1 expression and activated the GC cells, whereas Notch1 downregulation had the opposite effect. Notch1 exhibited varying effects on Snail in the GC cell lines. The downregulation of COX-2 expression significantly inhibited the proliferation of GC cells. On the whole, the expression of Notch signalling molecules differed in GC. COX-2 inversely regulated Notch1 in GC and partially depended on the Notch1 signalling pathway in altering the expression of Snail.
\end{abstract}

Correspondence to: Dr Yongning Zhou, Division of Gastroenterology and Hepatology, The First Hospital of Lanzhou University, Lanzhou, Gansu 730000, P.R. China

E-mail: yongningzhou@sina.com

${ }^{*}$ Contributed equally

Key words: Notch1, Jagged1, Snail, cyclooxygenase-2, gastric cancer

\section{Introduction}

Gastric cancer (GC) is a multifactorial disease with a specific pathogenicity mechanism that remains unclear, but which may be related to diet, lifestyle, or Helicobacter pylori infection. Mutations in susceptibility genes and epigenetic changes also play important roles in GC (1-3). Tumour invasion and metastasis are important factors affecting prognosis, which is the most difficult aspect of treating malignant tumours.

Cyclooxygenase (COX) has been considered a potential target for the treatment and prevention of tumours (4). COX-2 promotes the malignancy of cells by upregulating the production of prostaglandins, primarily prostaglandin E2 (PGE2) (5). COX-2 is associated with the tumourigenesis, histological subtype, tumour size and developmental stage of GC (6-10) through multiple pathways, such as angiogenesis, tumour growth, invasion and immune evasion (11-14).

The Notch family consists of four important signalling receptors, and the binding of the corresponding ligand releases the intracellular domain, which enters the nucleus and regulates gene expression by binding to downstream target gene loci (15). The Notch family is involved in the initiation and development of various tumours (16-20). The binding of Notch1 to the Jagged1 ligand can activate the STAT3/Twist signalling pathway and regulate the growth of GC cells (21). Notch 2 promotes the growth and metastasis of bladder tumours through cellular processes, such as epithelial-to-mesenchymal transition (EMT), the cell cycle and pluripotency (22). A high expression of Notch3 in non-small cell lung cancer is related to drug resistance and poor prognosis in patients, as well as the expression of the cancer stem cell markers, CD44 and aldehyde dehydrogenase 1 family, member A1 (ALDH1A1); thus, the inhibition of Notch3 expression can reduce the clonogenic ability and 'stem-like' property of lung cancer cells (23). The Snail family is a superfamily of zinc-finger transcription factors that mainly binds to promoters of various effector proteins to regulate transcription and protein expression (24).

In this study, the expression of Notch family members and COX-2 in 51 pairs of GC and paracancerous tissues was examined to determine their correlation with the clinicopathological features of GC. The changes in Notch and COX-2 expression in GC cell lines treated with celecoxib, PGE2 and small 
interfering RNA (siRNA) clarified that the Notch family and COX-2 are involved in GC tumourigenesis, providing a novel and useful target for the treatment of GC.

\section{Materials and methods}

Tissue samples. GC cells and paracancerous tissues $(>5 \mathrm{~cm}$ from the tumour foci and with the absence of cancerous cells confirmed by hematoxylin and eosin staining) were collected for experimental research from 51 patients with GC who received surgical treatment at Wuwei Cancer Hospital of Gansu province (China) from October 2009 to April 2010. This study was approved by the Ethical Board of Wuwei Cancer Hospital and the Ethical Board of the First Hospital of Lanzhou University. No patient had received radiotherapy or chemotherapy prior to surgery. A total of 51 pairs of cancerous and paracancerous tissues were sampled intraoperatively, placed immediately in liquid nitrogen, and then transferred to a $-80^{\circ} \mathrm{C}$ freezer for long-term storage. All patients provided informed consent. All cases were diagnosed by two experienced pathologists.

Antibodies and reagents. Horseradish peroxidase-conjugated goat anti-rabbit IgG (ZB-2301) was purchased from Beijing Zhongshan Golden Bridge Biological Technology Co., Ltd. (Beijing, China). Antibodies against the Notch1 intracellular domain (N1IC; ab83232), Snail (ab82846), the Notch2 intracellular domain (N2IC; ab8927) and COX-2 (ab15191) were purchased from Abcam (Cambridge, UK). The anti-GAPDH antibody (AB-P-R 001) was purchased from Hangzhou Goodhere Biotechnology Co., Ltd. (Hangzhou, China). Pure celecoxib was provided by Professor Joe Leung from the the University of Sydney. PGE2 was purchased from Cayman Chemical Co. (Ann Arbor, MI, USA), and the siRNA was designed and synthesised by Shanghai Invitrogen Biotechnology Co., Ltd. (Shanghai, China).

RNA extraction and fluorescence-based quantitative PCR ( $q P C R)$. RNA was extracted using RNAiso Plus (Takara Bio, Inc., Kusatsu, Japan) according to the manufacturer's instructions. Total RNA was reverse-transcribed using a PrimeScript ${ }^{\circledR}$ RT Master Mix (Perfect Real-Time) kit (Takara Bio, Inc.) according to the manufacturer's instructions. PCR was performed on a LightCycler ${ }^{\circledR} 480$ System (Roche, Basel, Switzerland). The PCR results were analysed u7sing the $2^{-\Delta \Delta C T}$ method, and $\beta$-actin was selected as the reference gene.

Protein extraction and western blot analysis. Total protein was extracted using RIPA lysis buffer (Beyotime Institute of Biotechnology, Jiangsu, China). The total protein (30-40 $\mu \mathrm{g})$ was then subjected to sodium dodecyl sulfate-polyacrylamide gel electrophoresis and transferred onto polyvinylidene fluoride membranes. After blocking in 5\% skim milk at room temperature for $2 \mathrm{~h}$, the membranes were incubated overnight with specific antibodies at $4^{\circ} \mathrm{C}$, followed by $1-2 \mathrm{~h}$ of incubation with a goat anti-rabbit secondary antibody (ZB-2301; Beijing Zhongshan Golden Bridge Biological Technology Co., Ltd.) at room temperature. Finally, the Super ECL Plus Detection Reagent (Applygen Technologies, Inc., Beijing, China) was used to detect specific protein bands.
Cell culture. The GES-1 (immortalized human gastric epithelial mucosa cells) and AGS (GC cells) cell lines were purchased from the Beijing Institute of Tumour Cells; the SGC-7901, BGC-823, and MGC-803 GC cell lines were purchased from the Cell Bank of Committee on Type Culture Collection of Chinese Academy of Sciences. All cell lines were routinely cultured in DMEM supplemented with $10 \%$ fetal bovine serum, $100 \mathrm{U} / \mathrm{ml}$ penicillin and $100 \mathrm{U} / \mathrm{ml}$ streptomycin in an incubator maintained at $37^{\circ} \mathrm{C}$ and $5 \% \mathrm{CO}_{2}$.

Transfection. The siRNA used in this study was designed and synthesised by Shanghai Invitrogen Biotechnology Co., Ltd. si-Notch1 (sense, 5'-CAGGGAGCAUGUGUAACAUTT-3' and antisense, 5'-AUGUUACACAUGCUCCCUGTT-3') was used to target Notch1; si-COX-2 (sense, 5'-GCAGCUUCCUGA UUCAAAUTT-3' and antisense, 5'-AUUUGAAUCAGGAAG CUGCTT-3') was used to target COX-2; scramble siRNA (sense, 5'-UUCUCCGAACGUGUCACGUdTdT-3' and antisense, 5'-ACGMGACACGUUCGGAGAAdTdT-3') was used as a negative control. The mock group was untransfected cells. The concentration of all siRNAs was $33 \mathrm{nM}$. All siRNAs were chemically synthesized. Cells were inoculated and grown for $24 \mathrm{~h}$ prior to transfection, and the siRNA was transfected into the cells using Lipofectamine ${ }^{\mathrm{TM}} 2000$ (Invitrogen Co., Ltd., Carlsbad, CA, USA) according to the manufacturer's instructions.

Drug experiments. The gastric cancer cell lines were treated with celecoxib and PGE2. The concentration gradient of celecoxib treatment was $0,25,50,75,100 \mu \mathrm{mol} / 1$ and the intervention time of celecoxib was $0,24,48,72 \mathrm{~h}$. The concentration gradient of the PGE2 treatment was $0,1,5,10 \mu \mathrm{mol} / 1$, the intervention time of PGE2 was $0,6,12,24 \mathrm{~h}$.

In vitro cell proliferation assay. For growth curve experiments, the cells were plated in 96 -well plates at a density of $2 \times 10^{3}$ cells/well. Viable cells were assayed at 1, 2, 3, 4, 5 and 6 days. Cell proliferation assays were performed using a Cell Counting kit-8 (Beijing Zoman Biotechnology Co., Ltd., Beijing, China). Each experiment was performed in triplicate and repeated 3 times.

Statistical analysis. SPSS 16.0 statistical software (SPSS, Inc., Chicago, IL, USA) was used for data processing, and the measurement data are represented as the means \pm standard deviation. The mean values of paired samples were compared using a paired-samples t-test. Comparisons between 2 groups were analysed by an independent two-sample t-test, and comparisons among multiple groups were analysed by a one-way analysis of variance. The statistical significance threshold was 0.05 .

\section{Results}

Expression of Notch1, Notch2, Notch3, Jagged1 and COX-2 in GC, and their association with the clinicopathological characteristics of GC. qPCR and western blot analysis were performed to determine the expression levels of the aforementioned genes in 51 pairs of GC and paracancerous tissues. The Notch1 mRNA expression level in GC was $1.54 \pm 0.22$-fold higher $(\mathrm{P}=0.023)$ than that in paracancerous tissues (Fig. 1); however, the expression level of N1IC in GC $(0.29 \pm 0.30)$ 
A Notch1

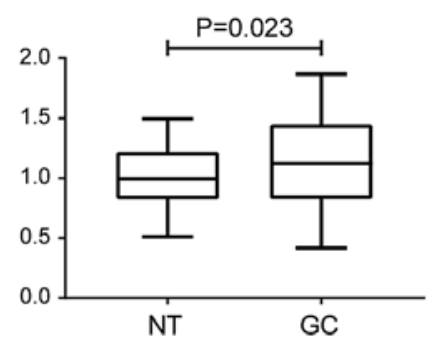

B

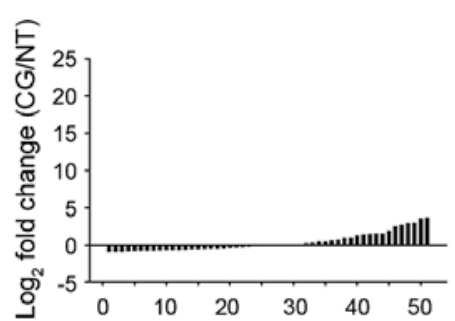

Notch2

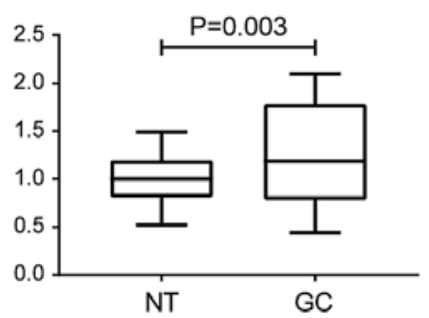

Jagged1

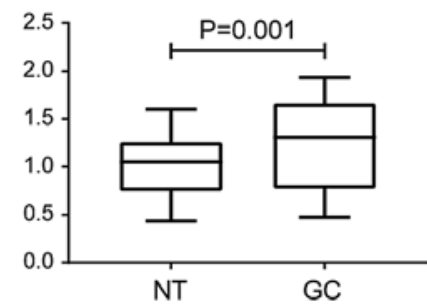

Clinical samples $(n=51)$
Notch3

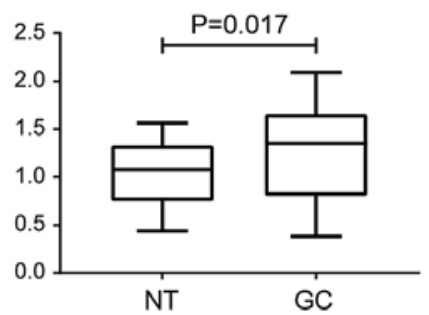

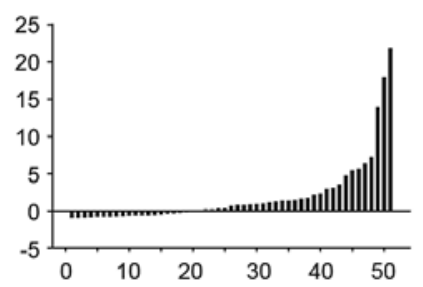
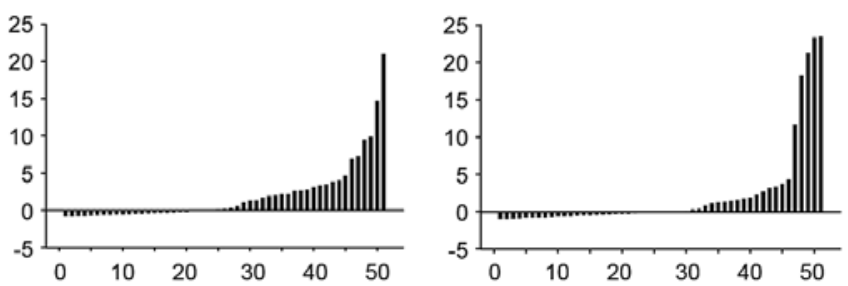

Clinical samples $(n=51)$

Figure 1. mRNA expression trend of Notch1, Notch2, Notch3 and Jagged1 in GC. (A) Expression levels of Notch1, Notch2, Notch3 and Jagged1 in 51 cases of GC were determined by qPCR, and the corresponding paracancerous tissues were used as controls to analyse the up- or downregulated fold change in target gene expression in GC. (B) Paired comparison of gene expression levels between primary GC samples and the corresponding paracancerous tissue samples. GC, gastric cancer.
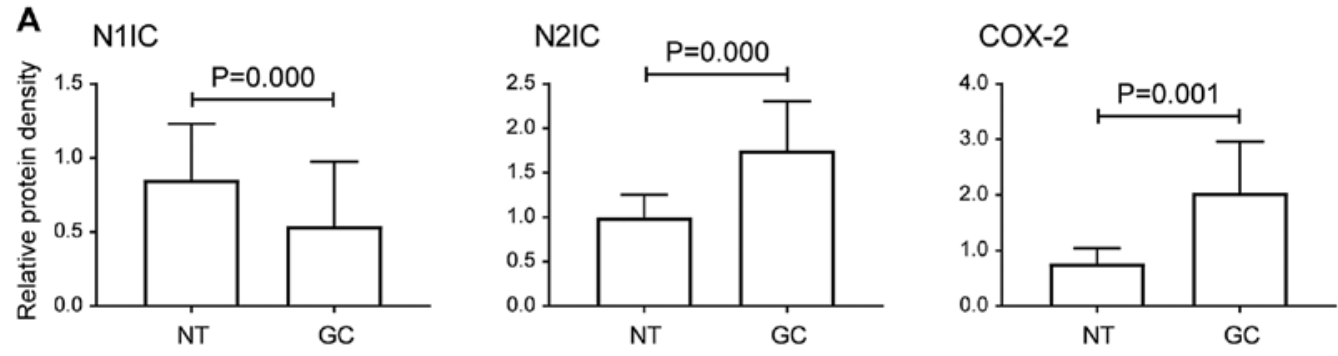

Clinical samples $(n=51)$

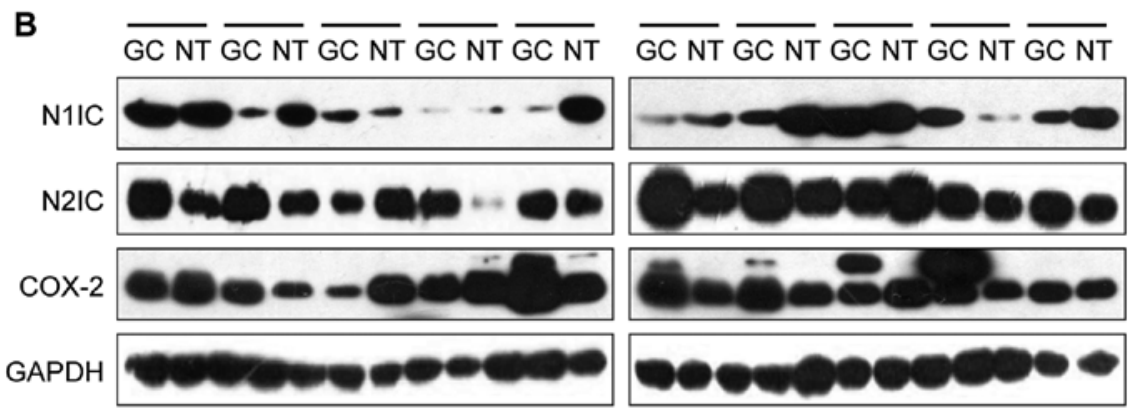

Figure 2. Expression pattern of N1IC, N2IC and COX-2 in GC and paracancerous tissues (NT) and the representative western blots. (A) The expression of N1IC, N2IC and COX-2 in 51 cases of GC and their corresponding paracancerous tissues were determined by western blot analysis using the target protein/GAPDH ratio for comparative analysis. (B) Representative western blots are shown. COX, cyclooxygenase; GC, gastric cancer.

was significantly decreased compared to the corresponding paracancerous tissues $(0.81 \pm 1.10 ; \mathrm{P}=0.000 ;$ Fig. $2 \mathrm{~A})$. The expression of Notch $2 \mathrm{mRNA}$ and N2IC in GC was significantly increased $(\mathrm{P}=0.003$ and $\mathrm{P}=0.000$, respectively; Figs. 1 and $2 \mathrm{~A})$. Similarly, Notch3 mRNA, Jagged 1 mRNA and COX-2 protein expression were at high levels in $\mathrm{GC}(\mathrm{P}=0.017, \mathrm{P}=0.001$, and $\mathrm{P}=0.001$, respectively; Figs. 1 and $2 \mathrm{~A}$ ). Clinicopathological analysis revealed that the expression levels of Notch1 mRNA and N1IC positively correlated with the depth of invasion and
TNM stage $(\mathrm{P}=0.003,0.002$; and $\mathrm{P}=0.027,0.014$, respectively; Tables I and II). The expression of COX-2 in the undifferentiated and poorly differentiated GC groups was significantly higher than that in the moderately and highly differentiated GC groups $(\mathrm{P}=0.012)$, and the expression levels increased with the depth of invasion ( $\mathrm{P}=0.026$; Table III). The results of Notch 3 mRNA expression are shown in Table IV. The mRNA expression of Notch3 was increased in GC and was significantly increased in the $\leq 50$-year-old GC group (Table IV); 
Table I. Correlation of Notch1 mRNA expression with various clinicopathological features of GC.

\begin{tabular}{|c|c|c|c|}
\hline Variable & $\begin{array}{l}\text { No. of } \\
\text { cases }\end{array}$ & $\begin{array}{l}\text { Notch1 mRNA } \\
\text { expression in GC }\end{array}$ & P-value \\
\hline \multicolumn{4}{|l|}{ Sex } \\
\hline Male & 34 & $1.3800 \pm 1.26$ & \multirow[t]{2}{*}{0.641} \\
\hline Female & 17 & $1.2048 \pm 1.24$ & \\
\hline \multicolumn{4}{|l|}{ Age (years) } \\
\hline$\leq 50$ & 17 & $1.5302 \pm 1.42$ & \multirow[t]{2}{*}{0.404} \\
\hline$>50$ & 34 & $1.2173 \pm 1.15$ & \\
\hline \multicolumn{4}{|l|}{ Degree of differentiation } \\
\hline $\begin{array}{l}\text { Well and moderately } \\
\text { differentiated }\end{array}$ & 21 & $1.1103 \pm 0.91$ & \multirow[t]{2}{*}{0.280} \\
\hline $\begin{array}{l}\text { Poorly and } \\
\text { undifferentiated }\end{array}$ & 30 & $1.4695 \pm 1.43$ & \\
\hline \multicolumn{4}{|c|}{ Depth of tumour invasion } \\
\hline $\begin{array}{l}\text { Mucosa, submucosa, } \\
\text { muscularis propria }\end{array}$ & 9 & $0.5429 \pm 0.63$ & \multirow[t]{2}{*}{$0.003^{\mathrm{a}}$} \\
\hline $\begin{array}{l}\text { Subserosa, serosa, } \\
\text { adjacent structures }\end{array}$ & 42 & $1.4885 \pm 1.28$ & \\
\hline \multicolumn{4}{|l|}{ TNM stage } \\
\hline Stage I/II & 11 & $0.6357 \pm 0.64$ & \multirow[t]{2}{*}{$0.002^{\mathrm{a}}$} \\
\hline Stage III/IV & 40 & $1.6548 \pm 1.31$ & \\
\hline \multicolumn{4}{|l|}{ Distant metastasis } \\
\hline Yes & 5 & $1.4048 \pm 1.25$ & \multirow[t]{2}{*}{0.882} \\
\hline No & 46 & $1.3126 \pm 1.26$ & \\
\hline
\end{tabular}

${ }^{\mathrm{a}} \mathrm{P}<0.05$ between the two groups. GC, gastric cancer.

COX-2 and Notch1 exhibit an inverse expression pattern in the normal human gastric mucosal cell line, GES-1, and different $G C$ cell lines. In the previous experiment, the expression of Notch family members and COX-2 in GC was found to be abnormal; specifically, there was a significant decrease in the intracellular domain of Notch1 in GC, whereas COX-2 expression was significantly increased. To explore the expression trend of Notch1 and COX-2 in GC cells, the expression of both genes was examined in the GES-1, AGS, SGC-7901, BGC-823, and MGC-803 cell lines. As shown in Fig. 3, compared with the normal gastric epithelial cell line, GES-1, Notch1 mRNA expression was decreased in the AGS, SGC-7901, and BGC-823 cells, but increased in the MGC-803 cells $(\mathrm{P}<0.05)$. The expression of COX-2 was increased in the AGS, SGC-7901, BGC-823 and MGC-803 cells compared with GES-1 cells $(\mathrm{P}<0.05)$. Fig. 4 shows that N1IC expression was significantly decreased in the AGS and SGC-7901 cells $(\mathrm{P}=0.017$ and 0.008 , respectively), but it was generally increased in the BGC-823 and MGC-803 cells. Unlike Notch1, COX-2 was more highly expressed in the AGS, SGC-7901 and BGC-823 cells ( $\mathrm{P}=0.000,0.000$, and 0.039 , respectively), but the expression was weak in MGC-803 cells. COX-2 expression therefore inversely correlated with Notch1 expression in GC cells, suggesting that there is an inverse regulatory relationship between COX-2 and Notch1 expression in GC cells.
Table II. Correlation of N1IC expression with various clinicopathological features of GC.

\begin{tabular}{lccc}
\hline Variable & $\begin{array}{c}\text { No. of } \\
\text { cases }\end{array}$ & $\begin{array}{c}\text { N1IC expression } \\
\text { in GC }\end{array}$ & P-value \\
\hline $\begin{array}{l}\text { Sex } \\
\text { Male }\end{array}$ & 34 & $0.2380 \pm 0.25$ & 0.072 \\
$\begin{array}{l}\text { Female } \\
\text { Age (years) }\end{array}$ & 17 & $0.3997 \pm 0.38$ & \\
$\leq 50$ & 17 & $0.2919 \pm 0.39$ & 0.911 \\
$>50$ & 34 & $0.2930 \pm 0.25$ & \\
$\begin{array}{l}\text { Degree of differentiation } \\
\text { Well and moderately }\end{array}$ & 21 & $0.1989 \pm 0.26$ & 0.058 \\
$\begin{array}{l}\text { differentiated } \\
\begin{array}{l}\text { Poorly and } \\
\text { undifferentiated }\end{array}\end{array}$ & 30 & $0.3570 \pm 0.32$ & \\
$\begin{array}{l}\text { Depth of tumour invasion } \\
\text { Mucosa, submucosa, }\end{array}$ & & & \\
muscularis propria & 9 & $0.1542 \pm 0.15$ & $0.027^{\mathrm{a}}$ \\
$\begin{array}{l}\text { Subserosa, serosa, } \\
\text { adjacent structures }\end{array}$ & 42 & $0.3214 \pm 0.32$ & \\
$\begin{array}{l}\text { TNM stage } \\
\text { Stage I/II }\end{array}$ & & & \\
$\begin{array}{l}\text { Stage III/IV } \\
\text { Distant metastasis }\end{array}$ & 11 & $0.1765 \pm 0.18$ & $0.014^{\mathrm{a}}$ \\
$\begin{array}{l}\text { Yes } \\
\text { No }\end{array}$ & 40 & $0.3678 \pm 0.34$ & \\
\hline
\end{tabular}

${ }^{a} \mathrm{P}<0.05$ between the two groups. GC, gastric cancer.

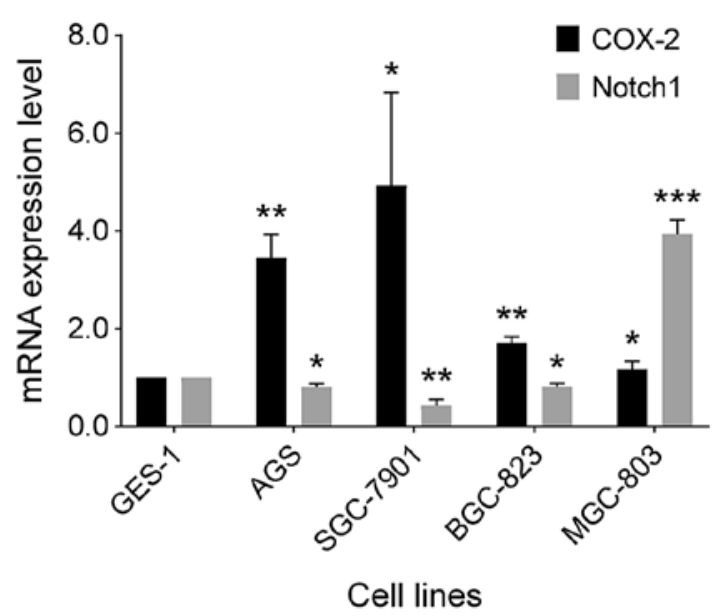

Figure 3. Differential mRNA expression of COX-2 and Notch1 in different cell lines. The expression of COX-2 and Notch1 in the normal gastric mucosal cell line, GES-1, and 4 human GC cell lines (AGS, SGC-7901, BGC-823, and MGC-803) was determined by qPCR. The GES-1 cell line was used as a control to analyse the mRNA expression of Notch1 and COX-2. ${ }^{*} \mathrm{P}<0.05,{ }^{* *} \mathrm{P}<0.01$, ${ }^{* * *} \mathrm{P}<0.001$ vs. the control. COX, cyclooxygenase; GC, gastric cancer.

Celecoxib regulates the expression of Notchl in GC cells, and PGE2 inhibits the expression of Notch1 in GC cells. We used pure celecoxib to inhibit COX-2 activity, while the administration 
Table III. Correlation of COX-2 protein expression with various clinicopathological features of GC.

\begin{tabular}{|c|c|c|c|}
\hline Variable & $\begin{array}{l}\text { No. of } \\
\text { cases }\end{array}$ & $\begin{array}{l}\text { COX-2 protein } \\
\text { expression in } \mathrm{GC}\end{array}$ & P-value \\
\hline \multicolumn{4}{|l|}{ Sex } \\
\hline Male & 34 & $2.0712 \pm 2.65$ & \multirow[t]{2}{*}{0.899} \\
\hline Female & 17 & $1.9790 \pm 1.91$ & \\
\hline \multicolumn{4}{|l|}{ Age (years) } \\
\hline$\leq 50$ & 17 & $1.7217 \pm 2.39$ & \multirow[t]{2}{*}{0.509} \\
\hline$>50$ & 34 & $2.1999 \pm 2.44$ & \\
\hline \multicolumn{4}{|l|}{ Degree of differentiation } \\
\hline $\begin{array}{l}\text { Well and moderately } \\
\text { differentiated }\end{array}$ & 21 & $1.0402 \pm 0.86$ & \multirow[t]{2}{*}{$0.012^{\mathrm{a}}$} \\
\hline $\begin{array}{l}\text { Poorly and } \\
\text { undifferentiated }\end{array}$ & 30 & $2.7407 \pm 1.27$ & \\
\hline \multicolumn{4}{|l|}{ Depth of tumour invasion } \\
\hline $\begin{array}{l}\text { Mucosa, submucosa, } \\
\text { muscularis propria }\end{array}$ & 9 & $1.3183 \pm 2.30$ & \multirow[t]{2}{*}{$0.026^{\mathrm{a}}$} \\
\hline $\begin{array}{l}\text { Subserosa, serosa, } \\
\text { adjacent structures }\end{array}$ & 42 & $3.1982 \pm 2.43$ & \\
\hline \multicolumn{4}{|l|}{ TNM stage } \\
\hline Stage I/II & 11 & $1.4399 \pm 1.32$ & \multirow[t]{2}{*}{0.750} \\
\hline Stage III/IV & 40 & $2.0756 \pm 1.98$ & \\
\hline \multicolumn{4}{|l|}{ Distant metastasis } \\
\hline Yes & 5 & $1.3733 \pm 1.08$ & \multirow[t]{2}{*}{0.251} \\
\hline No & 46 & $2.1130 \pm 2.51$ & \\
\hline
\end{tabular}

${ }^{\mathrm{a}} \mathrm{P}<0.05$ between the two groups. COX-2, cyclooxygenase-2; GC, gastric cancer.

of exogenous PGE2 was used to simulate the in vitro environment to induce a high COX-2 expression to further explore the regulatory relationship between Notch1 and COX-2. As shown in Figs. 5 and 6, celecoxib increased Notch1 mRNA and N1IC expression in the GC cells; Notch1 expression was increased in a dose-dependent manner over $48 \mathrm{~h}$ and exhibited an increasing trend with the treatment duration. Thus, celecoxib may upregulate the expression and activation of Notch1 in SGC-7901 and BGC-823 GC cells by inhibiting COX-2 activity. As shown in Figs. 7 and 8, following treatment of the SGC-7901 and BGC-823 cells with various concentrations of PGE2 for $24 \mathrm{~h}$, Notch1 expression was significantly decreased, and a decreasing trend in the expression of Notch1 was observed with the increasing PGE2 concentrations within a certain range. Notch1 expression in the two cell lines treated with $5 \mu \mathrm{M}$ PGE2 for 6,12 and $24 \mathrm{~h}$ decreased in relatively a time-dependent manner.

Effects of silencing of COX-2 and Notchl on the expression of Notch1, COX-2 and Snail in GC cells. The drug treatment results revealed a regulatory association between $\mathrm{COX}-2$ and Notch1. To verify these results, siRNAs were synthesised and transfected into the SGC-7901 and BGC-823 cells. The results are shown in Figs. 9 and 10. In the SGC-7901 cells, the COX-2 mRNA level in the cells transfected with
Table IV. Correlation of Notch3 expression with various clinicopathological features of GC.

\begin{tabular}{|c|c|c|c|}
\hline Variable & $\begin{array}{l}\text { No. of } \\
\text { cases }\end{array}$ & $\begin{array}{l}\text { Notch3 mRNA } \\
\text { expression in GC }\end{array}$ & P-value \\
\hline \multicolumn{4}{|l|}{ Sex } \\
\hline Male & 34 & $3.4135 \pm 1.07$ & \multirow[t]{2}{*}{0.768} \\
\hline Female & 17 & $4.2245 \pm 2.49$ & \\
\hline \multicolumn{4}{|l|}{ Age (years) } \\
\hline$\leq 50$ & 17 & $6.7857 \pm 2.88$ & \multirow[t]{2}{*}{$0.042^{\mathrm{a}}$} \\
\hline$>50$ & 43 & $2.1329 \pm 3.84$ & \\
\hline \multicolumn{4}{|l|}{ Degree of differentiation } \\
\hline $\begin{array}{l}\text { Well and moderately } \\
\text { differentiated }\end{array}$ & 21 & $4.1792 \pm 1.42$ & \multirow[t]{2}{*}{0.69} \\
\hline $\begin{array}{l}\text { Poorly and } \\
\text { undifferentiated }\end{array}$ & 30 & $3.3371 \pm 1.56$ & \\
\hline \multicolumn{4}{|c|}{ Depth of tumour invasion } \\
\hline $\begin{array}{l}\text { Mucosa, submucosa, } \\
\text { muscularis propria }\end{array}$ & 9 & $2.5124 \pm 2.91$ & \multirow[t]{2}{*}{0.65} \\
\hline $\begin{array}{l}\text { Subserosa, serosa, } \\
\text { adjacent structures }\end{array}$ & 42 & $3.7634 \pm 2.34$ & \\
\hline \multicolumn{4}{|l|}{ TNM stage } \\
\hline Stage I/II & 11 & $2.6076 \pm 1.30$ & \multirow[t]{2}{*}{0.482} \\
\hline Stage III/IV & 40 & $3.9145 \pm 1.29$ & \\
\hline \multicolumn{4}{|l|}{ Distant metastasis } \\
\hline Yes & 5 & $9.7968 \pm 11.16$ & \multirow[t]{2}{*}{0.062} \\
\hline No & 46 & $3.0194 \pm 7.12$ & \\
\hline
\end{tabular}

${ }^{\mathrm{a}} \mathrm{P}<0.05$ between the two groups. GC, gastric cancer.

siRNA against Notch1 (si-Notch1 group) was significantly increased $(\mathrm{P}=0.001)$. Compared with the cells transfected with siRNA against COX-2 (si-COX-2 group), the COX-2 protein level in the mock group was slightly increased, and the expression level of COX-2 in the co-transfection group was increased. In BGC-823 cells, the mRNA level of COX-2 in the co-transfection group was higher than that in the si-COX-2 group. In both cell lines, Notch1 mRNA expression in the si-COX-2 group was significantly increased $(\mathrm{P}=0.001$, $\mathrm{P}=0.019$ ), while N1IC expression was mildly increased, and N1IC expression in the co-transfection group of SGC-7901 cells was increased compared to that in the si-Notch1 group $(\mathrm{P}=0.024)$. The N1IC level in the co-transfected group of BGC-823 cells exhibited no significant changes compared with the control group. The mRNA and protein expression of Snail in the si-COX-2 group in both cell lines was significantly downregulated $(\mathrm{P}=0.036,0.000, \mathrm{P}=0.004,0.012)$. The mRNA expression of Snail in the si-Notch1 group in both cell lines was significantly increased $(\mathrm{P}=0.003, \mathrm{P}=0.001)$. The protein expression of Snail was upregulated in the si-Notch1 group of BGC-823 cells $(\mathrm{P}=0.004)$ and downregulated in the si-Notch1 group of SGC-7901 cells $(\mathrm{P}=0.003)$; however, the expression of Snail in the co-transfection group was higher than in the si-COX-2 group. 


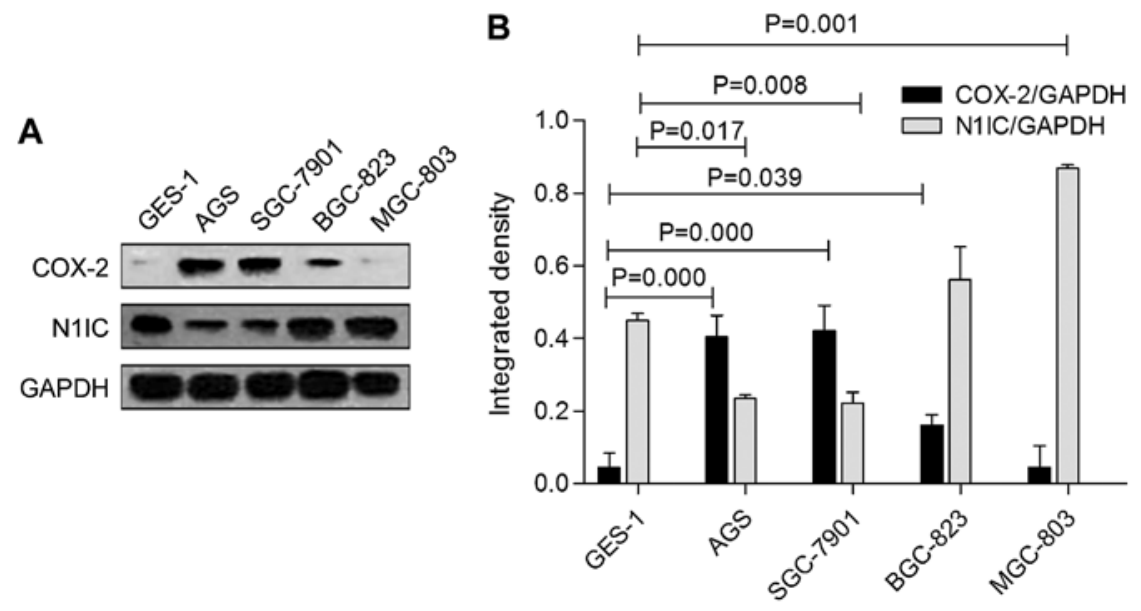

Figure 4. Differential expression of COX-2 and N1IC in different cell lines. (A) The expression levels of COX-2 and N1IC in GES-1, AGS, SGC-7901, BGC-823 and MGC-803 cells were determined by western blot analysis. (B) The relative quantification of bands was performed by the optical density scanning of (A). COX, cyclooxygenase.
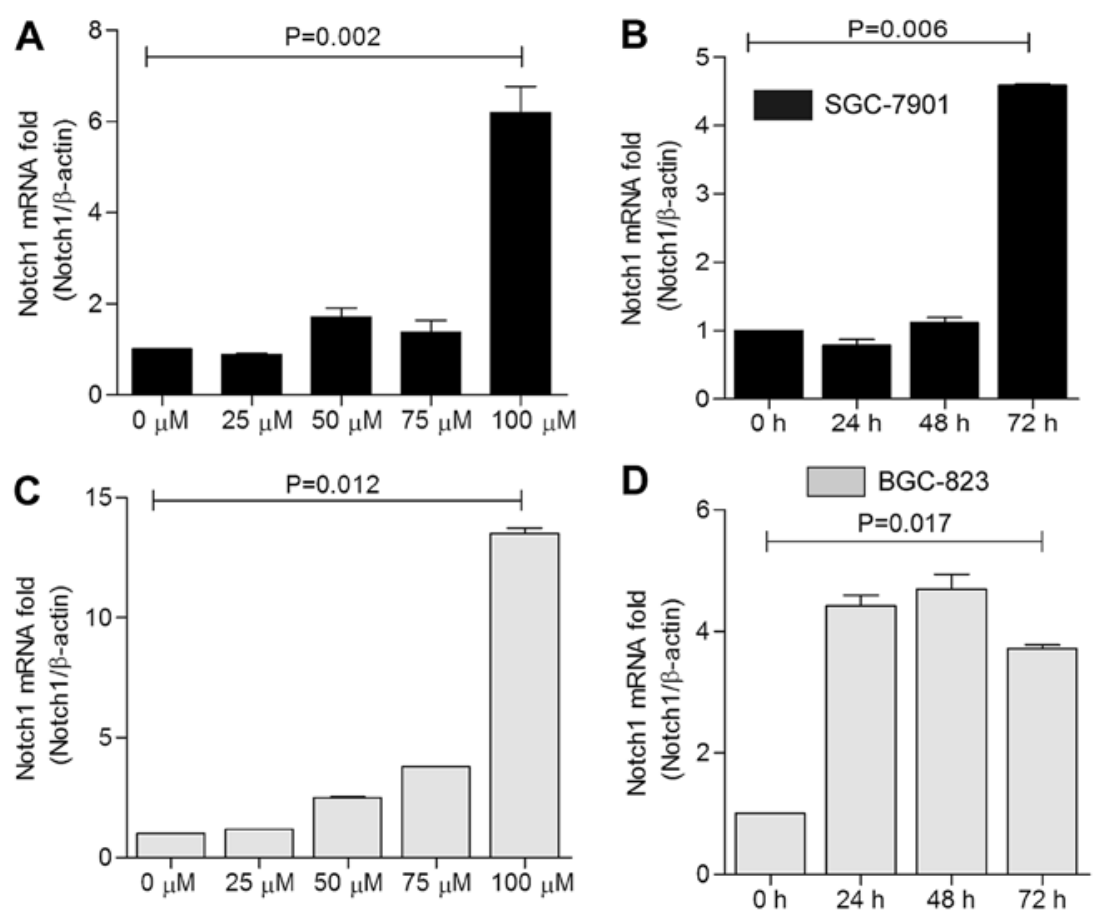

Figure 5. Notch1 mRNA expression trend in SGC-7901 and BGC-823 cells with celecoxib treatment concentration and time. Cells treated with 0, 25, 50, 75, and $100 \mu \mathrm{M}$ celecoxib for $48 \mathrm{~h}$ were used as the dose-dependent group, in which the $0 \mu \mathrm{M}$ group of (A) SGC-7901 and (C) BGC-823 cells was used as the control. Cells treated with $75 \mu \mathrm{M}$ celecoxib for $0,24,48$, and $72 \mathrm{~h}$ were considered the time-dependent group, in which the $0 \mathrm{~h}$ group of (B) SGC-7901 and (D) BGC-823 cells was used as the control. In both cell lines, treatment with $100 \mu \mathrm{M}$ celecoxib led to the most significant promoting effect on Notch1 mRNA expression $(\mathrm{P}=0.002, \mathrm{P}=0.012)$. In SGC-7901 cells, $72 \mathrm{~h}$ of treatment resulted in the most significant increase in the Notch1 mRNA level (P=0.006).

Downregulation of COX-2 inhibits GC proliferation in vitro. To investigate the role of COX-2 in GC growth, si-COX-2 or a control siRNA were transiently transfected into the SGC-7901 and BGC-823 cells, and the effects of the knockdown of COX-2 were determined by CCK- 8 proliferation assays. The downregulation of COX-2 expression significantly inhibited the proliferation of GC cells (Fig. 11).

\section{Discussion}

The Notch signalling pathway is a highly evolutionarily conserved signal transduction system (25). The Notch receptor transmits intracellular signals by interacting with ligands and plays important regulatory roles in cell proliferation, differentiation and apoptosis (26-28). Mammals possess four Notch receptors (Notch1-4), and Notch ligands include Jagged1, Jagged2, DLL1, DLL3 and DLL4 (29). Notch acts as an oncogene. Two large-scale whole-exome studies on chronic lymphocytic leukaemia (CLL) cases in Europe $(30,31)$ confirmed the presence of gain-of-function mutations in Notch1 in CLL. The abnormal increase in Notch1 activation due to mutations may be related to the poor prognosis of CLL. In breast cancer, Jagged1 can promote tumour metastasis by stimulating the secretion of interleukin-6 from osteoblasts (32), whereas the acti- 

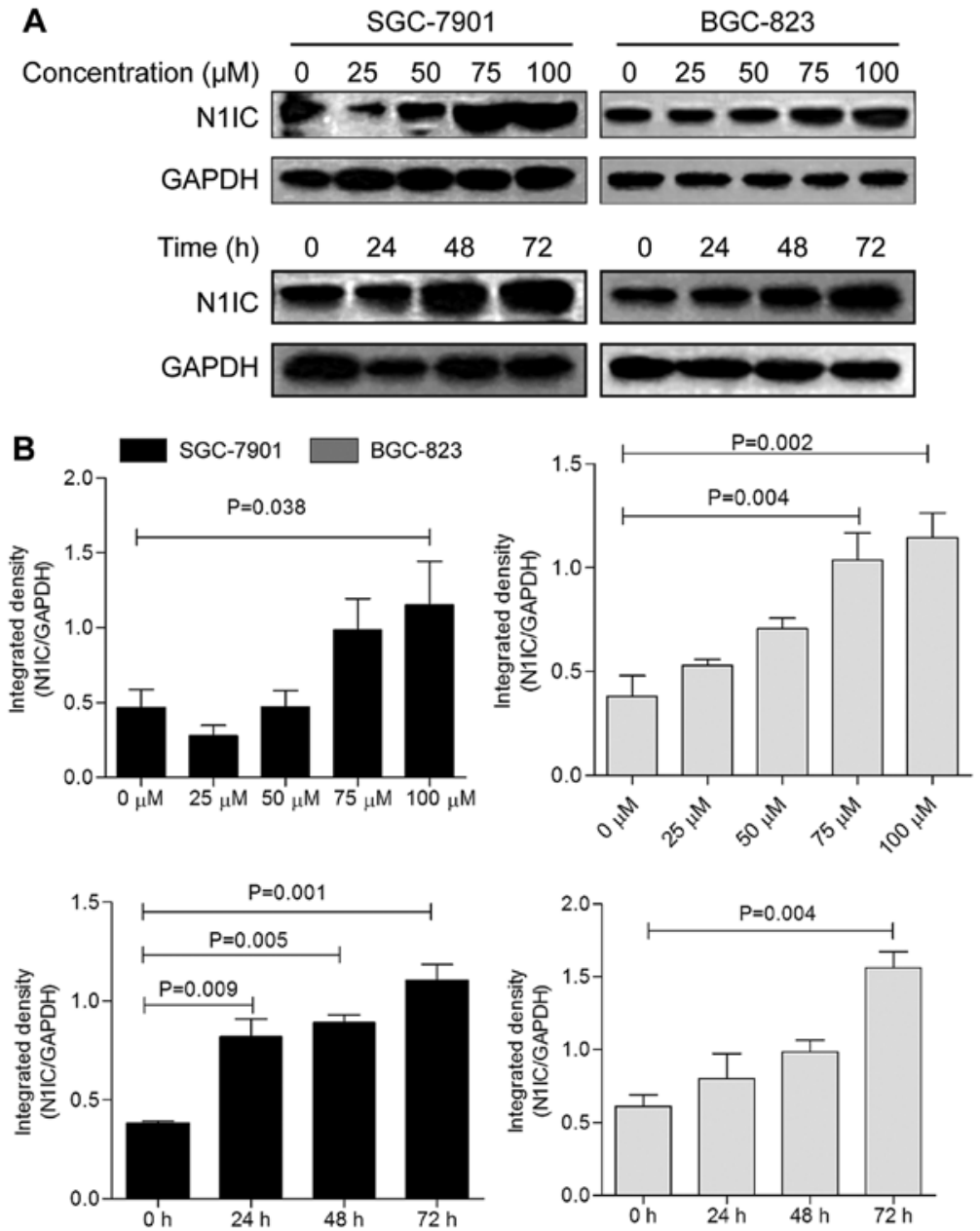

Figure 6. Time- and dose-dependent N1IC expression in celecoxib-treated SGC-7901 and BGC-823 cells. (A) After the two GC cell lines were treated with celecoxib at various concentrations and for different periods of time, N1IC expression was determined by western blot analysis. (B) Relative quantification of bands was performed by optical density scanning of (A). GC, gastric cancer.
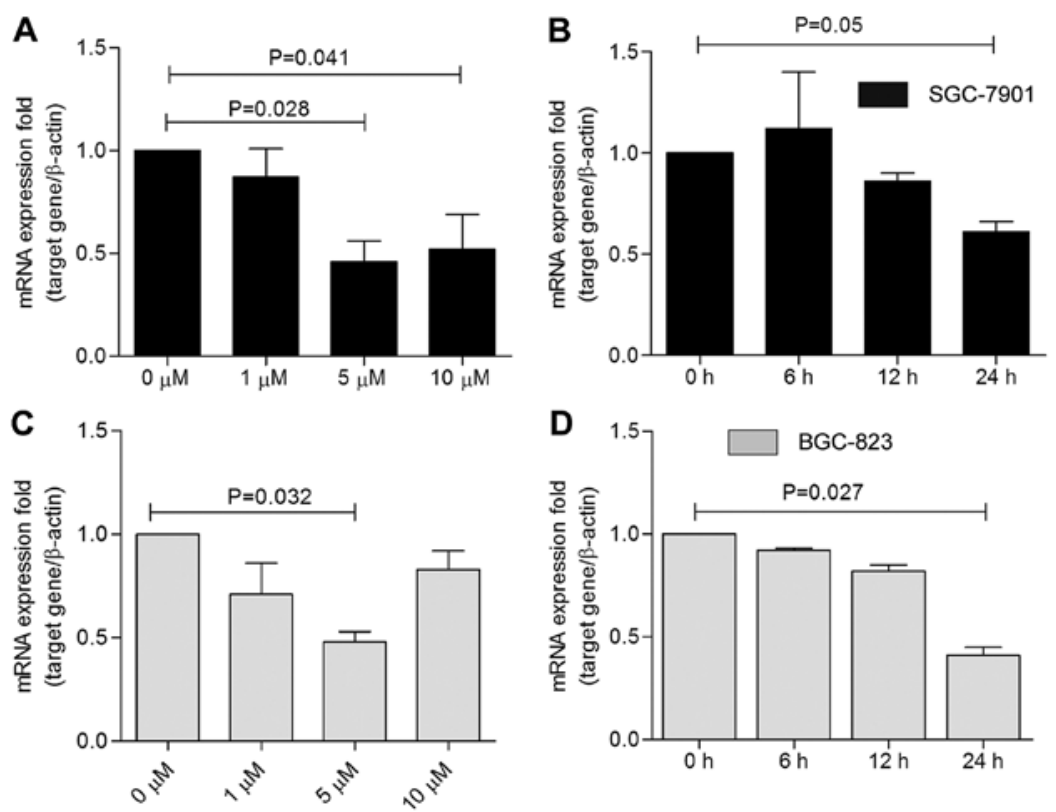

Figure 7. mRNA expression level of Notch1 in PGE2-treated SGC-7901 and BGC-823 cells. Cells treated with $0,1,5$, and $10 \mu \mathrm{M}$ PGE 2 for $24 \mathrm{~h}$ were used as the dose-dependent group, in which the $0 \mu \mathrm{M}$ group of (A) SGC-7901 and (C) BGC-823 cells was used as the control. Cells treated with $5 \mu \mathrm{M}$ PGE2 for 0, 6, 12, and $24 \mathrm{~h}$ were included in the time-dependent group, in which the $0 \mathrm{~h}$ group of (B) SGC-7901 and (D) BGC-823 cells was used as the control. In SGC-7901 cells, the 5 and $10 \mu \mathrm{M}$ groups showed the most significant Notch1 elevation compared with the control group $(\mathrm{P}=0.028, \mathrm{P}=0.041)$. In BGC-823 cells, treatment with $5 \mu \mathrm{M}$ PGE2 for $24 \mathrm{~h}$ resulted in the most significant reduction in Notch1 expression $(\mathrm{P}=0.032)$, and treatment for $24 \mathrm{~h}$ resulted in the most significant reduction in Notch1 mRNA ( $\mathrm{P}=0.027)$. $\mathrm{PGE} 2$, prostaglandin $\mathrm{E} 2$. 

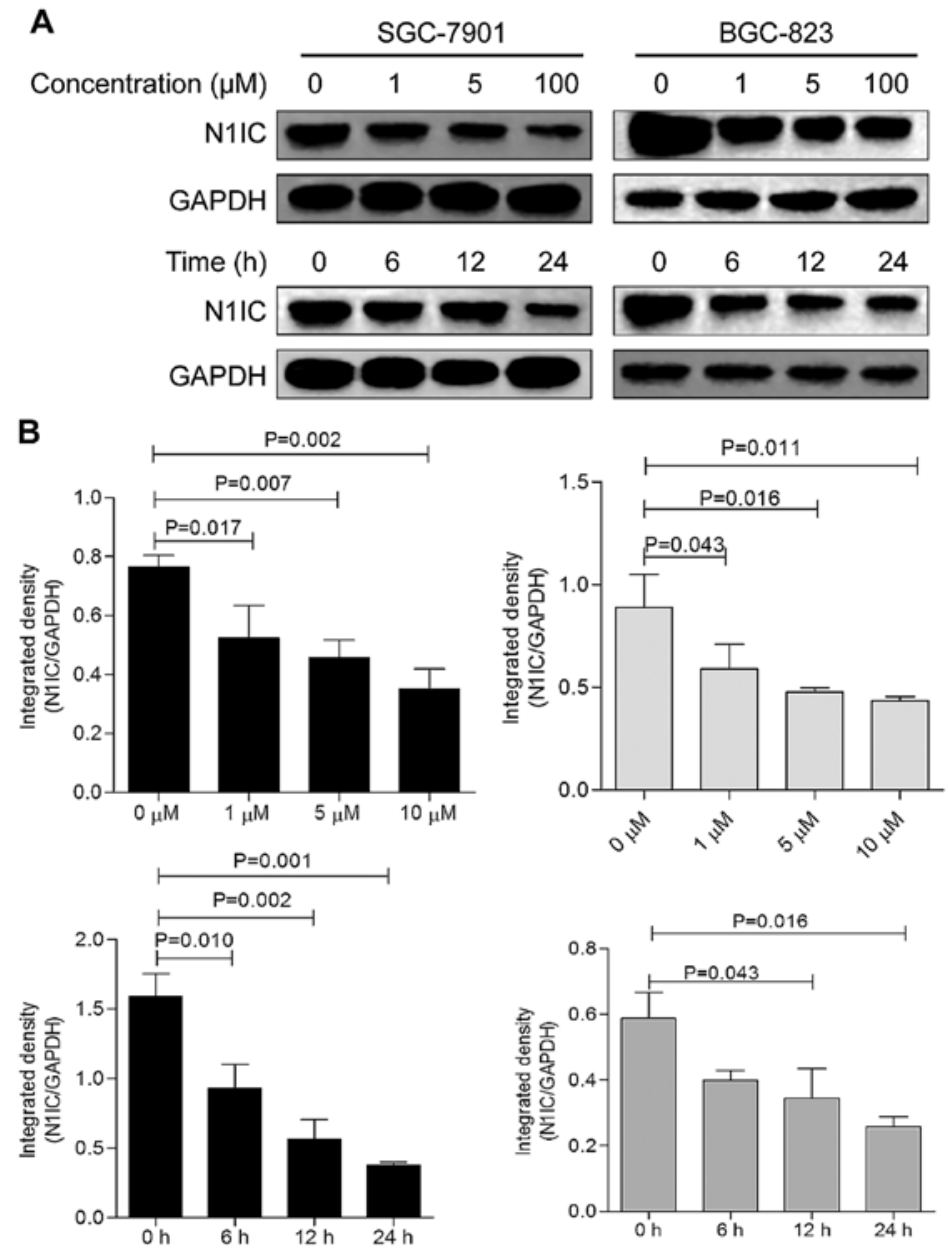

Figure 8. Dose- and time-dependent N1IC expression in PGE2-treated SGC-7901 and BGC-823 cells. (A) Following treatment with PGE2 at various concentrations for $24 \mathrm{~h}$, the N1IC expression level was decreased in a dose-dependent manner. With the increasing treatment time, the N1IC expression level was also decreased in a time-dependent manner. (B) Relative quantification of bands was performed by the optical density scanning of (A). PGE2, prostaglandin E2.

vation of Notch2 by benzyl isothiocyanate in cultured cells and xenografted tumours can promote the migration of breast cancer cells (33). Notch3 activation can induce EMT and suppress the carboplatin-induced apoptosis of the ovarian cancer cell line, OVCA429 (34). However, some studies have also suggested that the Notch signalling pathway can inhibit tumourigenesis and development. Notch1 deficiency in the skin and in primary keratinocytes can inhibit the $\beta$-catenin signalling pathway and inhibit differentiation and maturation in epidermal cells, leading to malignant transformation (35). In a K-ras allele-activated and Notch1-depleted mouse model, Notch1-depleted mice showed a significantly increased tumour incidence, suggesting that Notch1 acts as a tumour suppressor in pancreatic ductal adenocarcinoma (36). Notch activation has also been shown to be reduced following the administration of $\gamma$-secretase inhibitors, which can accelerate the growth of liver cancer cells, whereas the overexpression of Notch1 in the primary liver cancer cells of RB-p107-p130-deficient mice led to cell-cycle arrest and induced apoptosis. Similar experimental results were observed in the in vitro culture of two hepatocellular carcinoma cell lines (37).

In this study, the mRNA expression level of Notch1 was higher in GC tissues than in paracancerous tissues, while the overall expression level of N1IC in GC was significantly reduced compared with paracancerous normal gastric mucosa, indicating differences between the mRNA level and the activa- tion level of Notch1 in GC. The inhibition of Notch1 in GC may have a tumour-suppressing effect. Jagged1 mRNA, Notch2 mRNA and N2IC levels were upregulated in GC. As the activation of Notch proteins is influenced by the corresponding ligand, the abnormal mRNA expression of Jagged1 in GC may be one factor causing the abnormal activation of Notch proteins. However, reports on the function of enhanced Notch1 and Notch 2 activation in paracancerous tissues are relatively rare; hence, additional studies are required. The mRNA expression of Notch3 was increased in GC (Fig. 1) and significantly increased in the $\leq 50$-year-old GC group (Table IV); however, a larger sample size is needed to confirm these results.

Consistent with many previous studies (38-41), COX-2 expression was significantly increased in GC, and its expression was significantly higher in undifferentiated and poorly differentiated GC than in moderately and highly differentiated GC; additionally, COX-2 expression increased with the depth of invasion. Abnormal alterations in cell adhesion molecules and resulting adhesive behaviours occur during tumour cell invasion and metastasis (42-44). E-cadherin is a critical adhesion molecule, and Snail can directly inhibit E-cadherin transcription and expression by binding to the E-box of the E-cadherin promoter (45). The preliminary results of this study demonstrated that COX-2 had a regulatory effect on Snail (46); however, the mechanisms through which COX-2 regulates Snail expression 
A

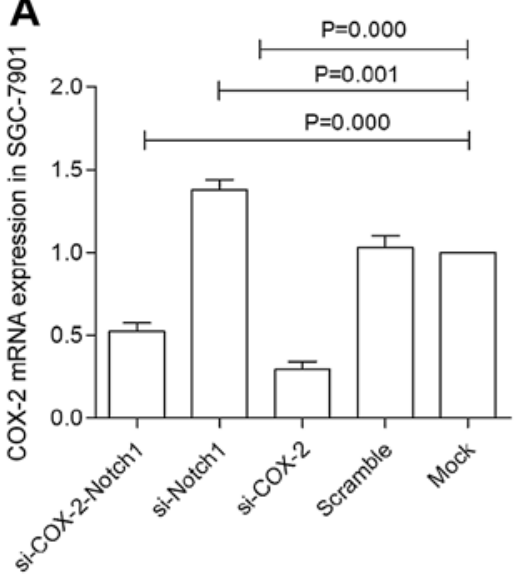

B

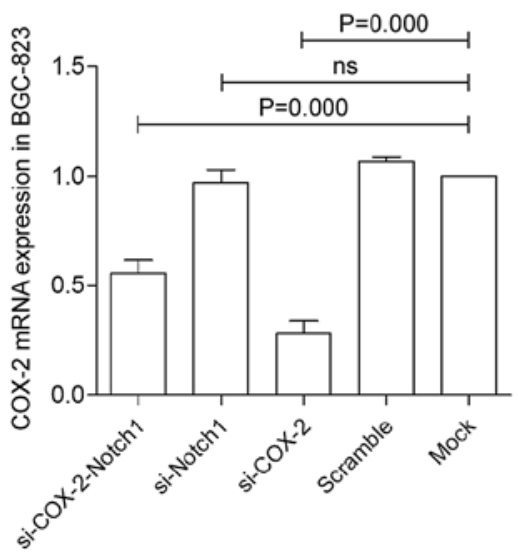

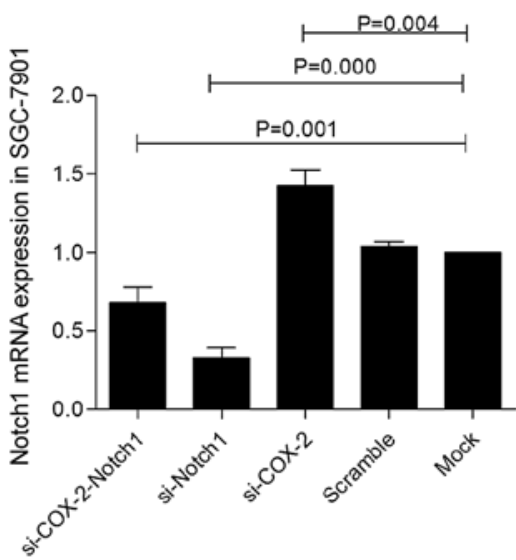
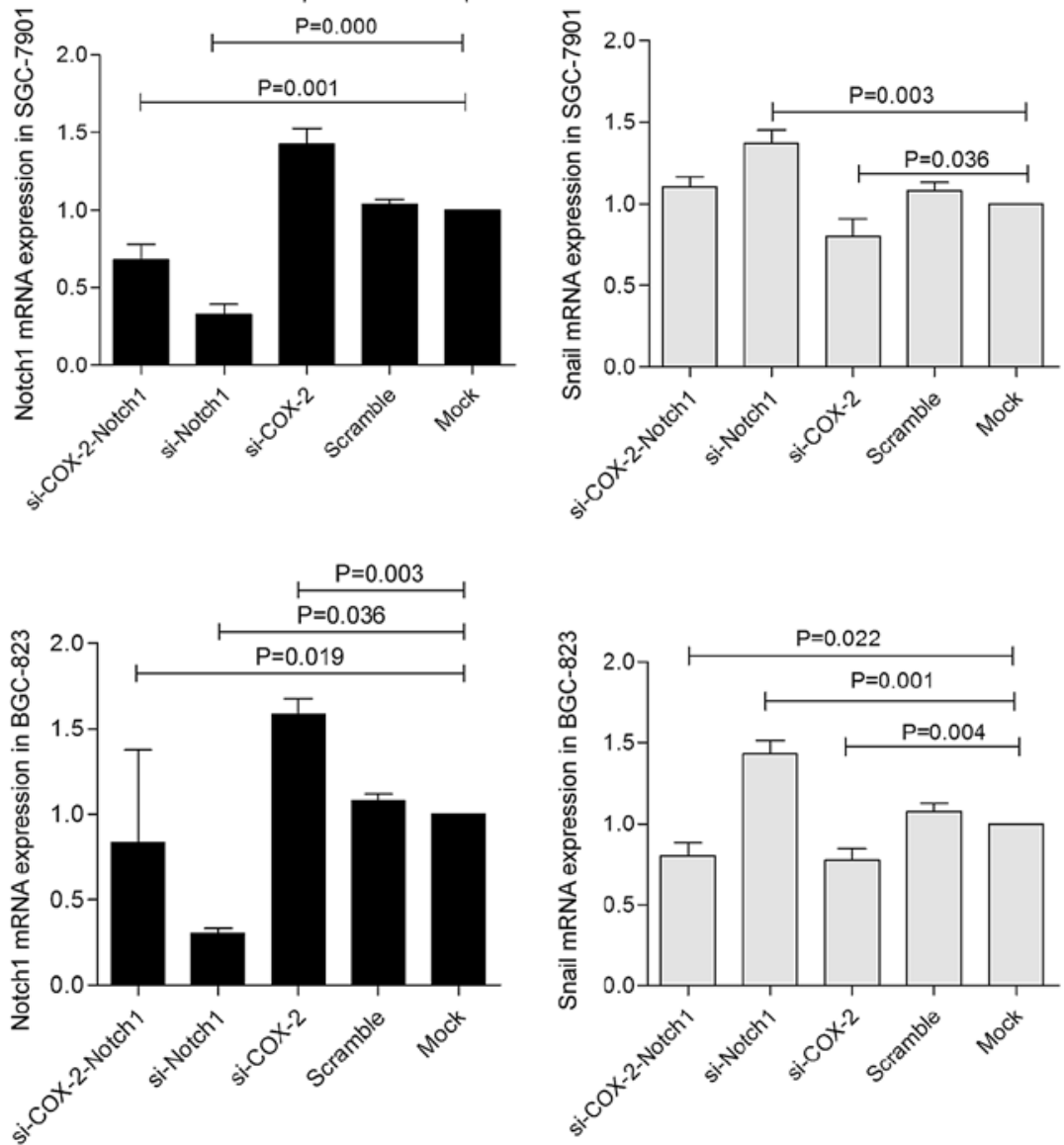

Figure 9. Changes in the mRNA expression levels of COX-2, Notch1 and Snail in siRNA-transfected SGC-7901 cells and BGC-823 cells. (A) SGC-7901 and (B) BGC-823 cells were transfected with si-Notch1, si-COX-2, or a scrambled siRNA. Forty-eight hours after transfection, total RNA was extracted to detect the mRNA of target genes (COX-2, Notch1, and Snail), using the mock group as the control for comparative analysis. COX, cyclooxygenase; siRNA, small interfering RNA.

A

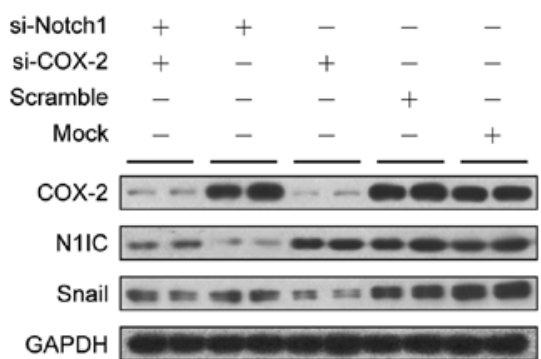

C

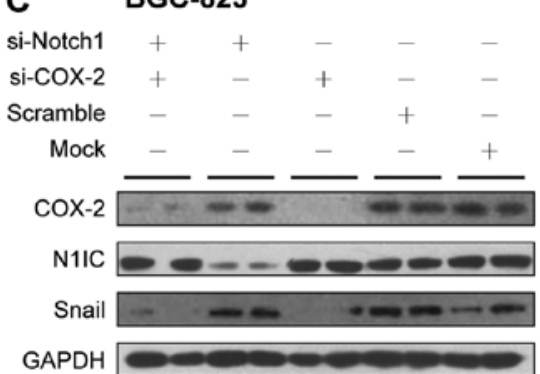

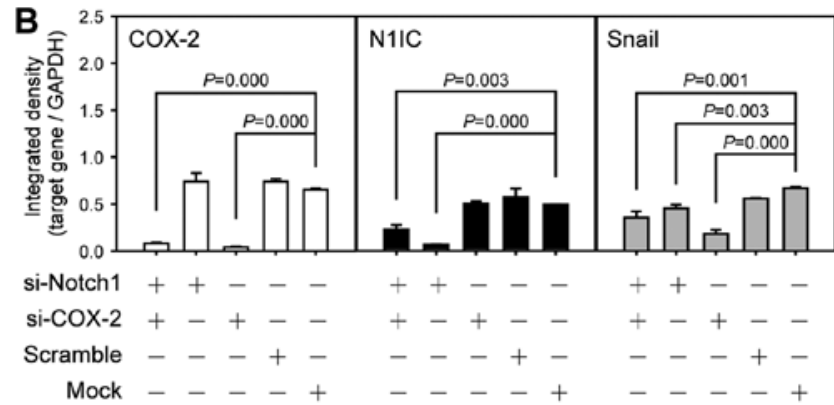

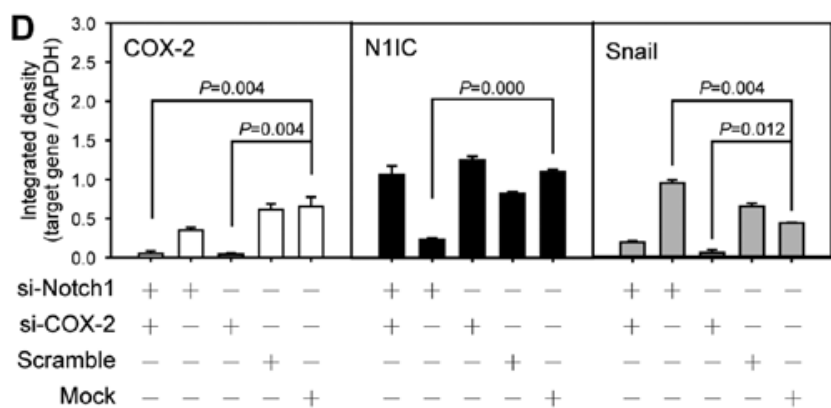

Figure 10. Changes in the expression levels of COX-2,N1IC and Snail in siRNA-transfected SGC-7901 and BGC-823 cells.(A and B) SGC-7901 and (C and D) BGC-823 cells were transfected with si-Notch1, si-COX-2, or a scrambled siRNA. Forty-eight hours after transfection, total protein was extracted to determine the expression levels of COX-2, N1IC and Snail, using the mock group as a control for comparative analysis. COX, cyclooxygenase; siRNA, small interfering RNA. 

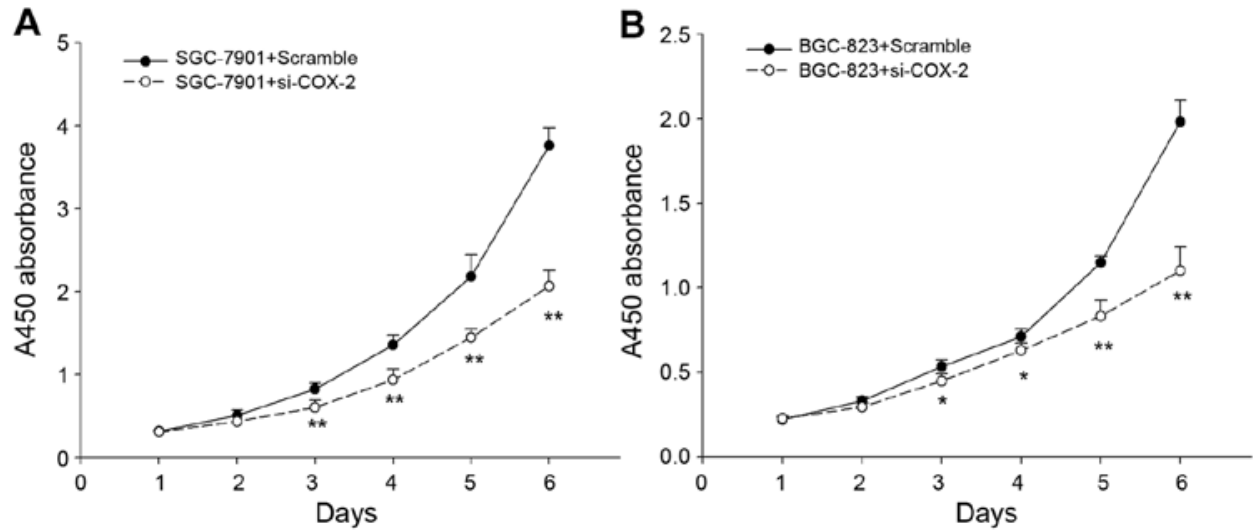

Figure 11. Inhibitory effects of COX-2 on the in vitro proliferation of SGC-7901 and BGC-823 cells. Following incubation in the culture medium of si-COX-2-transfected (A) SGC-7901 and (B) BGC-823 cells, the in vitro proliferation ability of GC cells was significantly decreased compared with the controls. ${ }^{*} \mathrm{P}<0.05,{ }^{* *} \mathrm{P}<0.01$. COX, cyclooxygenase; GC, gastric cancer.

remain unclear. Notch1 expression differed between different GC cell lines and was decreased in all cell lines that exhibited a high COX-2 expression. By contrast, COX-2 expression was decreased in cell lines with a high Notch1 expression. Thus, there was an inverse correlation between the expression of the two genes.

Following the inhibition of COX-2 activity with pure celecoxib, the expression of Notch1 was upregulated in a timeand dose-dependent manner, while it was downregulated in a time- and dose-dependent manner following the simulation of COX-2 expression in vitro by exogenous PGE2 administration. Thus, the ability of celecoxib and PGE2 to regulate the expression of Notch1 through COX-2 was evaluated. These observations provide new information regarding the association between COX-2 and Notch1. However, the antitumour effect of celecoxib also involves non-COX-2-dependent pathways, while PGE2 is only one of many prostaglandins produced by COX-2 catalysis. To verify the observations from the drug-based experiments, siRNAs were used to silence COX-2 and Notch1. The silencing of COX-2 expression significantly downregulated the expression of Snail in two GC cell lines, while the transcription and activation of Notch1 increased to varying degrees. These results indicate that COX-2 had a regulatory effect on Notch1, whereas the silencing of Notch1 expression had no significant effect on the expression of COX-2 in this experiment. There were differences in the effect of si-Notch1 treatment on Snail between the two GC cell lines; the silencing of Notch1 caused the downregulation of Snail expression in SGC-7901 cells and led to the upregulation of Snail expression in BGC-823 cells, which may be related to the different roles played by Notch1. The basal expression level of Notch1 varies in different cellular environments, and different downstream signal transduction pathways are activated in different cells. However, its specific mechanism must be confirmed in future experiments. Cell proliferation assays revealed that COX-2 downregulation significantly inhibited the proliferation of GC cells, suggesting that COX-2 could promote the angiogenesis of GC cells in vitro and that Notch1 may play a tumour suppressor role in GCs.

The regulation of COX-2 expression by Notch1 has been reported in previous studies $(47,48)$. In this study, we report that COX-2 knockdown led to the upregulation of the expression of Notch1. However, we believe that the regulatory relationship is likely to be indirect or a type of negative feedback regulation. Further studies are required to define the mode of regulation.

In conclusion, Notch family members were found to be involved in the tumourigenesis and development of GC and were associated with the clinicopathological features of GC. Moreover, different Notch family members may play different roles in GC. COX-2 can inversely regulate the expression and activation of Notch 1 and is partially dependent on the Notch1 pathway in altering the expression of Snail in GC. The results of this study revealed that COX-2 may be involved in the proliferation, invasion and migration of GC via different signal transduction pathways, providing a theoretical basis for the targeted molecular therapy of GC.

\section{Acknowledgements}

This study was supported by China's National Science and Technology Program for Public Wellbeing (grant no. 2012GS620101),National Natural Science Foundation of China (grant no. 81372145),Gansu Natural Science Foundation of China (grant no. 1606RJZA140 and 1606RJZA141), Gansu Science and Technology Support Plan (grant no. 1604FKCA105), Lanzhou Chengguan District Science and Technology Plan Project (grant no. 2014-4-3) and The First Hospital of Lanzhou University Foundation (grant no. ldyyyn2015-15).

\section{References}

1. Guggenheim DE and Shah MA: Gastric cancer epidemiology and risk factors. J Surg Oncol 107: 230-236, 2013.

2. Siegel RL, Miller KD and Jemal A: Cancer statistics, 2015. CA Cancer J Clin 65: 5-29, 2015.

3. Wang F, Meng W, Wang B and Qiao L: Helicobacter pylori-induced gastric inflammation and gastric cancer. Cancer Lett 345: 196-202, 2014

4. Wang ZL, Fan ZQ, Jiang HD and Qu JM: Selective Cox-2 inhibitor celecoxib induces epithelial-mesenchymal transition in human lung cancer cells via activating MEK-ERK signaling. Carcinogenesis 34: 638-646, 2013.

5. Liu X, Ji Q, Ye N, Sui H, Zhou L, Zhu H, Fan Z, Cai J and Li Q: Berberine inhibits invasion and metastasis of colorectal cancer cells via COX-2/PGE2 mediated JAK2/STAT3 signaling pathway. PLoS One 10: e0123478, 2015.

6. Schildberg C, Abbas M, Merkel S, Agaimy A, Dimmler A, Schlabrakowski A, Croner R, Leupolt J, Hohenberger W and Allgayer H: COX-2, TFF1, and Src define better prognosis in young patients with gastric cancer. J Surg Oncol 108: 409-413, 2013. 
7. Shin WG, Kim HJ, Cho SJ, Kim HS, Kim KH, Jang MK, Lee JH and Kim HY: The COX-2-1195AA genotype is associated with diffuse-type gastric cancer in Korea. Gut Liver 6: 321-327, 2012.

8. Su HJ, Zhang Y, Zhang L, Ma JL, Li JY, Pan KF and You WC: Methylation status of COX-2 in blood leukocyte DNA and risk of gastric cancer in a high-risk Chinese population. BMC Cancer 15: 979, 2015.

9. Wu XL, Cheng B, Li PY, Huang HJ, Zhao Q, Dan ZL, Tian DA and Zhang P: MicroRNA-143 suppresses gastric cancer cell growth and induces apoptosis by targeting COX-2. World J Gastroenterol 19: 7758-7765, 2013.

10. Yuan XL, Chen L, Li MX, Dong P, Xue J, Wang J, Zhang TT, Wang XA,Zhang FM, Ge HL, et al: Elevated expression of Foxp3 in tumor-infiltrating Treg cells suppresses T-cell proliferation and contributes to gastric cancer progression in a COX-2-dependent manner. Clin Immunol 134: 277-288, 2010.

11. Cheng $\mathbf{J}$ and Fan XM: Role of cyclooxygenase-2 in gastric cancer development and progression. World J Gastroenterol 19 7361-7368, 2013.

12. Oshima $\mathrm{H}$ and Oshima $\mathrm{M}$ : The role of PGE2-associated inflammatory responses in gastric cancer development. Semin Immunopathol 35: 139-150, 2013.

13. Yao L, Liu F, Hong L, Sun L, Liang S, Wu K and Fan D: The function and mechanism of COX-2 in angiogenesis of gastric cancer cells. J Exp Clin Cancer Res 30: 13, 2011.

14. Zhang P, Luo HS, Li M and Tan SY: Artesunate inhibits the growth and induces apoptosis of human gastric cancer cells by downregulating COX-2. Onco Targets Ther 8: 845-854, 2015.

15. Guruharsha KG, Kankel MW and Artavanis-Tsakonas S: The Notch signalling system: Recent insights into the complexity of a conserved pathway. Nat Rev Genet 13: 654-666, 2012.

16. Bertrand FE, Angus CW, Partis WJ and Sigounas G: Developmental pathways in colon cancer: Crosstalk between WNT, BMP, Hedgehog and Notch. Cell Cycle 11: 4344-4351, 2012.

17. Domingo-Domenech J, Vidal SJ, Rodriguez-Bravo V, Castillo-Martin M, Quinn SA, Rodriguez-Barrueco R, Bonal DM, Charytonowicz E, Gladoun N, de la Iglesia-Vicente J, et al: Suppression of acquired docetaxel resistance in prostate cancer through depletion of notch- and hedgehog-dependent tumor-initiating cells. Cancer Cell 22: 373-388, 2012.

18. Garner JM, Fan M, Yang CH, Du Z, Sims M, Davidoff AM and Pfeffer LM: Constitutive activation of signal transducer and activator of transcription 3 (STAT3) and nuclear factor $\kappa \mathrm{B}$ signaling in glioblastoma cancer stem cells regulates the Notch pathway. J Biol Chem 288: 26167-26176, 2013.

19. Hassan KA, Wang L, Korkaya H, Chen G, Maillard I, Beer DG, Kalemkerian GP and Wicha MS: Notch pathway activity identifies cells with cancer stem cell-like properties and correlates with worse survival in lung adenocarcinoma. Clin Cancer Res 19: 1972-1980, 2013

20. McAuliffe SM, Morgan SL, Wyant GA, Tran LT, Muto KW, Chen YS, Chin KT, Partridge JC, Poole BB, Cheng KH, et al Targeting Notch, a key pathway for ovarian cancer stem cells, sensitizes tumors to platinum therapy. Proc Natl Acad Sci USA 109: E2939-E2948, 2012.

21. Hsu KW, Hsieh RH, Huang KH, Fen-Yau Li A, Chi CW, Wang TY, Tseng MJ, Wu KJ and Yeh TS: Activation of the Notch1/STAT3/Twist signaling axis promotes gastric cancer progression. Carcinogenesis 33: 1459-1467, 2012.

22. Hayashi T, Gust KM, Wyatt AW, Goriki A, Jäger W, Awrey S, Li N, Oo HZ, Altamirano-Dimas M, Buttyan R, et al: Not all NOTCH is created equal: The oncogenic role of NOTCH2 in bladder cancer and its implications for targeted therapy. Clin Cancer Res 22: 2981-2992, 2016.

23. Ma Y, Li M, Si J, Xiong Y, Lu F, Zhang J, Zhang L, Zhang P and Yang Y: Blockade of Notch3 inhibits the stem-like property and is associated with ALDH1A1 and CD44 via autophagy in non-small lung cancer. Int J Oncol 48: 2349-2358, 2016.

24. Wang Y, Shi J, Chai K, Ying X and Zhou BP: The role of Snail in EMT and tumorigenesis. Curr Cancer Drug Targets 13: 963-972, 2013.

25. Hori K, Sen A and Artavanis-Tsakonas S: Notch signaling at a glance. J Cell Sci 126: 2135-2140, 2013.

26. Acar A, Simões BM, Clarke RB and Brennan K: A role for Notch signalling in breast cancer and endocrine resistance. Stem Cells Int 2016: 2498764, 2016.

27. Braune EB and Lendahl U: Notch - a goldilocks signaling pathway in disease and cancer therapy. Discov Med 21: 189-196, 2016.

28. Kumar R, Juillerat-Jeanneret L and Golshayan D: Notch antagonists: Potential modulators of cancer and inflammatory diseases. J Med Chem 59: 7719-7737, 2016.
29. Penton AL, Leonard LD and Spinner NB: Notch signaling in human development and disease. Semin Cell Dev Biol 23: 450-457, 2012.

30. Fabbri G, Rasi S, Rossi D, Trifonov V, Khiabanian H, Ma J, Grunn A, Fangazio M, Capello D, Monti S, et al: Analysis of the chronic lymphocytic leukemia coding genome: Role of NOTCH1 mutational activation. J Exp Med 208: 1389-1401, 2011.

31. Puente XS, Pinyol M, Quesada V, Conde L, Ordóñez GR, Villamor N, Escaramis G, Jares P, Beà S, González-Díaz M, et al: Whole-genome sequencing identifies recurrent mutations in chronic lymphocytic leukaemia. Nature 475: 101-105, 2011.

32. Sethi N, Dai X, Winter CG and Kang Y: Tumor-derived JAGGED1 promotes osteolytic bone me-tastasis of breast cancer by engaging notch signaling in bone cells. Cancer Cell 19: 192-205, 2011.

33. Kim SH, Sehrawat A and Singh SV: Notch2 activation by benzyl isothiocyanate impedes its inhibitory effect on breast cancer cell migration. Breast Cancer Res Treat 134: 1067-1079, 2012.

34. Gupta N, Xu Z, El-Sehemy A, Steed H and Fu Y: Notch3 induces epithelial-mesenchymal transition and attenuates carboplatin-induced apoptosis in ovarian cancer cells. Gynecol Oncol 130: 200-206, 2013.

35. Nicolas M, Wolfer A, Raj K, Kummer JA, Mill P, van Noort M, Hui CC, Clevers H, Dotto GP and Radtke F: Notch1 functions as a tumor suppressor in mouse skin. Nat Genet 33: 416-421, 2003.

36. Hanlon L, Avila JL, Demarest RM, Troutman S, Allen M Ratti F, Rustgi AK, Stanger BZ, Radtke F, Adsay V, et al: Notch1 functions as a tumor suppressor in a model of K-ras-induced pancreatic ductal adenocarcinoma. Cancer Res 70: 4280-4286, 2010.

37. Viatour P, Ehmer U, Saddic LA, Dorrell C, Andersen JB, Lin C, Zmoos AF, Mazur PK, Schaffer BE, Ostermeier A, et al: Notch signaling inhibits hepatocellular carcinoma following inactivation of the RB pathway. J Exp Med 208: 1963-1976, 2011.

38. Fanelli MFLTDC, Chinen LT, Begnami MD, Costa WL Jr, Fregnami JH, Soares FA and Montagnini AL: The influence of transforming growth factor- $\alpha$, cyclooxygenase-2, matrix metalloproteinase (MMP)-7, MMP-9 and CXCR4 proteins involved in epithelial-mesenchymal transition on overall survival of patients with gastric cancer. Histopathology 61: 153-161, 2012.

39. Lazăr D, Tăban S, Ardeleanu C, Simionescu C, Sporea I, Cornianu $\mathrm{M}$ and Vernic C: Immuno-histochemical expression of the cyclooxygenase-2 (COX-2) in gastric cancer. The correlations with the tumor angiogenesis and patients' survival. Rom J Morphol Embryol 49: 371-379, 2008

40. Song J, Bai Z and Zhang Z: MicroRNAs are implicated in the initiation and progression of gastric cancer. Chin Med J (Engl) 127: 554-559, 2014

41. Yu CH, Li L, Li YM, Zhang BF, Fang J, Zhou Q, Hu Y and Gao HJ: Expression of tissue microarray p53, p16 and cyclooxygenase-2 in gastric cancer. Zhonghua Nei Ke Za Zhi 45: 658-660, 2006 (In Chinese).

42. Patriarca C, Macchi RM, Marschner AK and Mellstedt H: Epithelial cell adhesion molecule expression (CD326) in cancer: A short review. Cancer Treat Rev 38: 68-75, 2012.

43. Valiente M, Obenauf AC, Jin X, Chen Q, Zhang XH, Lee DJ, Chaft JE, Kris MG, Huse JT, Brogi E, et al: Serpins promote cancer cell survival and vascular co-option in brain metastasis. Cell 156: 1002-1016, 2014.

44. Zhang X, Yue P, Page BD, Li T, Zhao W, Namanja AT, Paladino D, Zhao J, Chen Y, Gunning PT, et al: Orally bioavailable small-molecule inhibitor of transcription factor Stat3 regresses human breast and lung cancer xenografts. Proc Natl Acad Sci USA 109: 9623-9628, 2012

45. Spaderna S, Schmalhofer O, Wahlbuhl M, Dimmler A, Bauer K, Sultan A, Hlubek F, Jung A, Strand D, Eger A, et al: The transcriptional repressor ZEB1 promotes metastasis and loss of cell polarity in cancer. Cancer Res 68: 537-544, 2008

46. Chen Z, Liu M, Liu X, Huang S, Li L, Song B, Li H, Ren Q, Hu Z, Zhou $\mathrm{Y}$, et al: COX-2 regulates E-cadherin expression through the NF- $\mathrm{B}$ /Snail signaling pathway in gastric cancer. Int J Mol Med 32: 93-100, 2013

47. Yu LX, Zhou L, Li M, Li ZW, Wang DS and Zhang SG: The Notch1/cyclooxygenase-2/Snail/E-cadherin pathway is associated with hypoxia-induced hepatocellular carcinoma cell invasion and migration. Oncol Rep 29: 362-370, 2013.

48. Zhou L, Wang DS, Li QJ, Sun W, Zhang Y and Dou KF: The down-regulation of Notch1 inhibits the invasion and migration of hepatocellular carcinoma cells by inactivating the cyclooxygenase-2/Snail/E-cadherin pathway in vitro. Dig Dis Sci 58: $1016-1025,2013$ 